\title{
FOREWORD FOR ARTICLES OF GASTON BERGER ST. LOUIS, SENEGAL
}

This volume of the African Law Study Library bringing together a series of reflections produced by young researchers from the Faculty of Law and Political Science of Gaston Berger St. Louis University (UGB) falls under the context of the recent changes of the Senegalese public law. The contributions are the fruits of an extension of a successful collaboration arising from discussions on the rule of law and democracy in Senegal. The UGB team thus dedicated itself in identifying different specific aspects for the realization of the concept of the rule of law in Senegal.

The articles focus mainly on the introduction of results-based management (RBM) in budgetary matters in Senegal: Medium term expenditure frameworks (MTEF), recent changes in decentralization in Senegal, academic freedom in Senegal, financial laws in Senegal, budgetary balance in Senegalese law and community bases of Senegalese budgetary law

We sincerely thank all our partners for having made possible this project which enables young researchers to familiarize themselves with university publications.

Hartmut Hamann

Ibrahima Diallo 